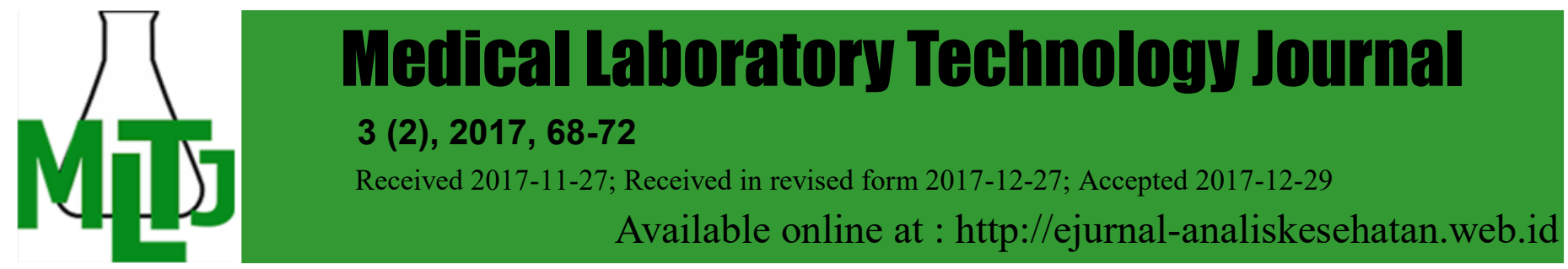

\title{
SERUM LIPEMIK DENGAN FLOKULAN GAMMA-SIKLODEKSTRIN PADA PEMERIKSAAN GLUKOSA
}

\author{
Alde Fajar Pambudi, Subrata Tri Widada, Budi Setiawan \\ Jurusan Analis Kesehatan Poltekkes Kemenkes Yogyakarta \\ JI Ngadinegaran MJ III/ 62 Yogyakarta \\ e-mail: budisetiawantropmed@gmail.com
}

\begin{abstract}
Lipemic serum caused by lipoprotein particles such as chylomicrons, VLDL (Very Low-Density Lipoprotein) and triglycerides. This situation causes interference chromophoric photometric analysis, interference on the wavelength and light scattering caused by the presence of lipid particles. This study aims to determine and differences glucose levels in lipemic serum with and without the addition of gamma-cyclodextrin incubation temperature $23^{\circ} \mathrm{C}$. The study's pre-experimental use research design static group comparison. The samples were all lipemic serum many as 20 samples. The research findings were the glucose levels without adding the flocculant Gamma-cyclodextrin incubation temperature $23^{\circ} \mathrm{C}$ was $267,19 \mathrm{mg} / \mathrm{dl}$. Whereas the glucose levels with adding the flocculant Gamma-cyclodextrin incubation temperature $230 \mathrm{C}$ was $169,23 \mathrm{mg} / \mathrm{dl}$. The difference of glucose levels with or without adding the flocculant Gamma-cyclodextrin incubation temperature $230 \mathrm{C}$ was $97,96 \mathrm{mg} / \mathrm{dl}(35,23 \%)$.
\end{abstract}

Keywords: glucose levels; lipemic serum; gamma-cyclodextrin flocculant

Abstrak: Serum lipemik disebabkan partikel lipoprotein seperti cylomicrons, VLDL (Verry Low Density Lipoprotein) maupun trigliserida. Keadaan ini menyebabkan gangguan kromoforik dalam analisis fotometri, gangguan pada panjang gelombang dan hamburan cahaya yang disebabkan oleh adanya partikel lipid. Penelitian ini bertujuan untuk mengetahui perbedaan dan selisih rata-rata kadar glukosa dalam serum lipemik dengan dan tanpa penambahan gamma-siklodekstrin inkubasi suhu $23^{\circ} \mathrm{C}$. Penelitian pre eksperimen ini menggunakan design penelitian static group comparison. Sampel penelitian adalah semua serum lipemik sebanyak 20 sampel. Hasil penelitian yang telah dilakukan didapatkan rerata kadar glukosa pada serum lipemik tanpa penambahan flokulan Gamma-siklodekstrin inkubasi suhu $23^{\circ} \mathrm{C}$ adalah 267,19 $\mathrm{mg} / \mathrm{dl}$, rerata kadar glukosa serum lipemik dengan penambahan flokulan Gamma-siklodekstrin inkubasi suhu $23^{\circ} \mathrm{C}$ adalah $169,23 \mathrm{mg} / \mathrm{dl}$. Perbedaan hasil pemeriksaan kadar glukosa dengan dan tanpa penambahan flokulan Gamma-siklodekstrin inkubasi suhu $23^{\circ} \mathrm{Cadalah} 97,96 \mathrm{mg} / \mathrm{dl}$ $(35,23 \%)$.

Kata kunci: flokulan gamma-siklodekstrin; kadar glukosa; serum lipemik 


\section{PENDAHULUAN}

Serum lipemik menyebabkan gangguan kromoforik dalam analisis seperti fotometri karena pembacaan latar belakang yang tinggi, gangguan pada pengukuran panjang gelombang dan pembenturan cahaya disebabkan substansi - substansi pengganggu (Anderson, 2015) Serum lipemik pada prinsipnya disebabkan oleh adanya partikel besar lipoprotein seperti chylomicrons atau Very Low Density Lipoprotein (VLDL) dan komponen lipid utama yaitu trigliserida (Piyophirapong, 2010.,Usha A 2016).

Lipemik dapat mengganggu dalam setiap uji yang menggunakan transmisi cahaya. Faktor yang mengganggu adalah kekeruhan yang terdapat pada sampel lipemik. Kekeruhan dalam sampel lipemik dapat mengganggu pemeriksaan secara spektrofotometer, turbidimetri, maupun nephelometri karena menghamburkan cahaya dan penyerapan cahaya (Sacher, R. 2004).

Serum lipemik dapat ditangani dengan beberapa cara, salah satunya melalui pendinginan selama 12 sampai 16 jam yang akan memberikan informasi yang cepat mengenai kadar kilomikron dan VLDL serum dengan kadar trigliserida berlebihan, namun cara pendiaman yang dilakukan terhadap serum lipemik tidak dianjurkan karena akan menunda waktu pemeriksaan (Piyophirapong, 2010). Penanganan serum lipemik secara konvensional menggunakan ultrasentrifugasi. Metode ultrasentrifugasi ini efektif, akan tetapi membutuhkan alat tambahan yang cukup mahal bagi laboratorium kecil dan laboratorium satelit (Cynthia M. Roberts and S.W. Cotton, 2013).

Metode lain yang dapat dilakukan adalah metode ekstraksi dengan pelarut organik seperti eter dan kloroform untuk menghilangkan lipid pada serum manusia, namun penggunaan pelarut organik seperti kloroform dan eter sudah jarang dipakai karena bahan ini bersifat karsinogenik yang membahayakan teknisi laboratorium dan lingkungan (Castro, A.R. 2000).

Penelitian Cynthia, Roberts, Cotton (2013) menunjukkan bahwa $78 \%$ sampel dengan penambahan siklodekstrin menunjukkan tingkat lipemik yang lebih rendah dibanding dengan metode ultrasentrifugasi karena penghilang lipid pengganggu lebih maksimal.
Menurut Caligur (2008), Gamma-siklodekstrin memiliki kelarutan dan rongga yang lebih besar dibandingkan dengan Alfa-siklodekstrin dan Beta-siklodekstrin sehingga dapat menerima banyak molekul. Gammasiklodekstrin memiliki kemampuan untuk membentuk kompleks inklusi dengan molekul yang ditahan dalam rongga molekul siklodekstrin. Rongga lipofilik molekul siklodekstrin menyediakan lingkungan mikro yang sesuai ukuran gugus non-polar sehingga dapat masuk untuk membentuk kompleks inklusi (Putri, D.K. 2016).

Penelitian ini bertujuan untuk mengetahui perbedaan kadar glukosa pada serum lipemik dengan dan tanpa penambahan flokulan gamma-siklodekstrin pada inkubasi suhu $23^{\circ} \mathrm{C}$.

\section{BAHAN DAN METODE}

Penelitian ini merupakan penelitian Pra Eksperimen (pre-experimental design) dengan menggunakan Static Group Comparison. Penelitian dilakukan di Laboratorium Klinik Jurusan Analis Kesehatan Yogyakarta pada bulan MaretApril 2017. Serum yang digunakan untuk penelitian sebanyak 20 sampel dengan kriteria kadar trigliserida $>300 \mathrm{mg} / \mathrm{dl}$ yang didapatkan dari Laboratorium Klinik RSUP Dr. Sardjito, sampel serum lipemik untuk perlakukan dan kontrol berasal dari sampel serum yang sama. Serum lipemik yang dipilih adalah serum lipemik yang tidak ikterik dan tidak hemolisis. Sampel langsung diperiksa kadar glukosa untuk kontrol, kemudian sampel serum dengan penambahan Gammasiklodekstrin konsentrasi $20 \%$ dengan perbandingan 2 : 1 atau $0.5 \mathrm{ml}$ serum dan 0.25 $\mathrm{ml}$ larutan Gamma-siklodekstrin untuk perlakukan. Serum kemudian di inkubasi pada suhu $23{ }^{\circ} \mathrm{C}$ selama 5 menit lalu dilakukan sentifugasi dengan kecepatan 3000 rpm selama 5 menit. Supernatan yang jernih diambil dan dilakukan pemeriksaan kadar glukosa. Pemeriksaan kadar glukosa dilakukan dengan metode glukosa oksidase/ peroksidase (GOD/POD). Data yang diperoleh dianalisis secara deskriptif yang disertai penyajian dalam bentuk diagram batang. 
Medical Laboratory Technology Journal

\section{HASIL DAN PEMBAHASAN}

Berdasarkan hasil penelitian terhadap 20 sampel yang lipemik didapatkan hasil sebagai berikut:

Tabel 1. Distribusi Frekuensi Jumlah Sampel Berdasarkan Kadar Trigliserida

\begin{tabular}{|c|c|c|c|c|}
\hline $\begin{array}{l}\text { Warna dan } \\
\text { kekeruhan }\end{array}$ & $\begin{array}{c}\text { Kadar } \\
\text { trigliserid }\end{array}$ & $\begin{array}{l}\text { Rata-rata } \\
\text { kadar } \\
\text { trigliserid } \\
\text { (mg/dl) }\end{array}$ & $\begin{array}{l}\text { Tingkat } \\
\text { lipemik }\end{array}$ & Jumlah \\
\hline Putih susu & $300-499$ & 370 & Ringan & 12 \\
\hline $\begin{array}{l}\text { Putih susu dan } \\
\text { keruh }\end{array}$ & $500-799$ & 776.5 & Sedang & 2 \\
\hline $\begin{array}{l}\text { Putih susu dan } \\
\text { sangat keruh }\end{array}$ & $800-1800$ & 1147.5 & Berat & 6 \\
\hline
\end{tabular}

Data rerata selisih hasil pemeriksaan kadar glukosa serum lipemik dengan dan tanpa penambahan gamma-siklodekstrin yang diinkubasi suhu $23^{\circ} \mathrm{C}$ dapat dilihat pada gambar 1.

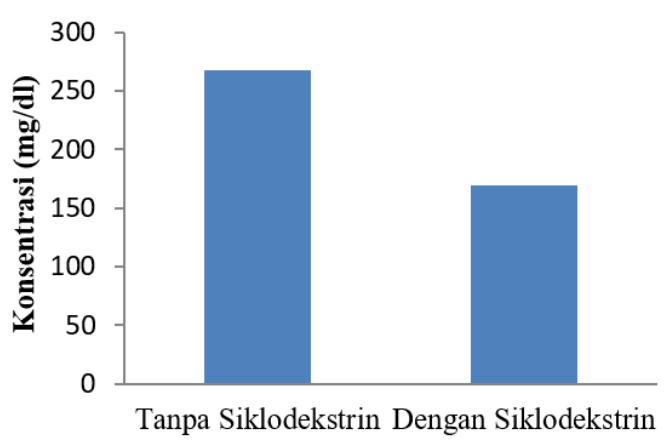

- Nilai Target

Gambar 1. Rerata Hasil Pemeriksaan Kadar Glukosa dengan dan tanpa penambahan Gamma-Siklodekstrin pada inkubasi suhu $23^{\circ} \mathrm{C}$

Pemeriksaan kadar glukosa dengan penambahan flokulan gamma-siklodesktrin yang diinkubasi suhu $23^{\circ} \mathrm{C}$ lebih rendah dari kadar glukosa tanpa penambahan flokulan Gamma-siklodekstrin yang diinkubasi suhu $23^{\circ} \mathrm{C}$ dengan rerata selisih $97,97 \mathrm{mg} / \mathrm{dl}$, dilihat pada gambar 1 diagram rerata kadar glukosa, hal ini disebabkan oleh flokulan gammasiklodekstrin yang dapat menjernihkan serum lipemik dengan mengikat molekul lipoprotein.

Tabel 2.Rerata Selisih Kadar Glukosa Dengan dan Tanpa Penambahan GammaSiklodekstrin Inkubasi Suhu $23{ }^{\circ} \mathrm{C}$ Berdasarkan Tingkat Lipemik.

\begin{tabular}{|c|c|c|c|c|}
\hline \multirow{2}{*}{$\begin{array}{l}\text { Tingkat } \\
\text { Lipemik }\end{array}$} & \multicolumn{2}{|c|}{$\begin{array}{l}\text { Rata-Rata Kadar } \\
\text { Glukosa (mg/dL) }\end{array}$} & \multirow{2}{*}{$\begin{array}{l}\text { Selisih Kadar } \\
\quad(\mathrm{mg} / \mathrm{dL})\end{array}$} & \multirow{2}{*}{$\begin{array}{c}\text { Persentase } \\
\text { Selisih } \\
\text { Kadar (\%) }\end{array}$} \\
\hline & $\begin{array}{c}\text { Tanpa } \\
\text { ditambah } \\
\text { flokulan }\end{array}$ & $\begin{array}{l}\text { Dengan } \\
\text { ditambah } \\
\text { flokulan }\end{array}$ & & \\
\hline Ringan & 261,13 & 166,22 & 94,90 & 35 \\
\hline Sedang & 284,23 & 138,85 & 145,38 & 48 \\
\hline Berat & 273,65 & 185,37 & 88,28 & 32 \\
\hline
\end{tabular}

Pada tabel 2. rerata selisih hasil pemeriksaan kadar glukosa dengan tingkat lipemik ringan sebesar 94,90 (35\%), sedangkan tingkat lipemik sedang sebesar $145,38(48 \%)$ dan tingkat lipemik berat sebesar 88,28 (32\%). Hasil pemeriksaan kadar albumin dengan tingkat lipemik sedang memiliki rerata selisih yang paling kecil, hal ini diakibatkan bahan pemeriksaannya hanya berjumlah dua, dibandingkan hasil pemeriksaan kadar glukosa dengan tingkat lipemik lain yang memiliki rerata selisih yang hampir sama dengan jumlah sampel masingmasing sembilan.

Hasil penelitian serum lipemik dengan penambahan flokulan gamma-siklodekstrin yang diinkubasi suhu $23^{\circ} \mathrm{C}$ secara visual terlihat lebih jernih setelah dilakukan pemusingan dengan kecepatan $3000 \mathrm{rpm}$ selama 5 menit. Pemeriksaan kadar glukosa dengan penambahan flokulan gamma-siklodesktrin yang diinkubasi suhu $23^{\circ} \mathrm{C}$ lebih rendah dari kadar glukosa tanpa penambahan flokulan Gamma-siklodekstrin yang diinkubasi suhu $23^{\circ} \mathrm{C}$ dengan rerata selisih $97,97 \mathrm{mg} / \mathrm{dl}$, hal ini disebabkan oleh flokulan gamma-siklodekstrin yang dapat menjernihkan serum lipemik dengan mengikat molekul lipoprotein. Penambahan flokulan gamma-siklodekstrin pada sampel serum lipemik akan mengikat molekul lipoprotein, sehingga lipoprotein akan terendapkan setelah dilakukan pemusingan dan serum menjadi jernih. Supernatan jernih yang dihasilkan diperiksa kadar glukosa sehingga didapatkan hasil yang akurat.

Penanganan serum lipemik yang populer dilakukan di lapangan adalah dengan metode ultrasentrifugasi, ekstraksi, dan flokulasi. Pada penelitian ini menggunakan gamma-siklodekstrin. Goal Standard untuk penanganan serum lipemik di laboratorium adalah menggunakan ultrasentrifugasi (Calmarza P, Cordero J,2011). 
Berdasarkan penelitian yang dilakukan Sharma pada tahun 1990, membandingkan penggunaan flokulan alfa-siklodekstrin dengan metode ultrasentrifugasi menunjukkan hasil tidak ada perbedaan yang signifikan diantara keduanya.

Hasil yang sama juga didapatkan pada penelitian Robert pada tahun 2013, yaitu menunjukkan bahwa $78 \%$ sampel yang dilakukan penanganan dengan siklodektrin menunjukkan tingkat lipemik yang lebih rendah daripada menggunakan ultrasentrifugasi (Roberts, C.M. 2013), selain itu penelitian menggunakan flokulan juga dilakukan oleh Dewanti Kurnia Putri pada tahun 2016. Hasil yang didapatkan menunjukkan rerata selisih $41,46 \mathrm{mg} / \mathrm{dl}$ dengan persentase selisih $20,95 \%$. Tidak ada perbedaan secara signifikan penggunaan flokulan alfa-siklodekstrin dengan gammasiklodekstrin (Putri, D.K. 2016). Penggunaan gamma-siklodekstrin juga dapat diterapkan pada sampel lipemik dengan parameter penggunaan yang berbeda, seperti untuk pemeriksaan protein total dan ureum, berdasarkan hasil penelitian terdapat perbedaan yang signifikan antara sebelum dan sesudah diberikan gamma-siklodekstrin (Sujono, S. 2016).

Serum lipemik yang langsung diperiksa mengakibatkan hasil tinggi palsu. Penambahan gamma-siklodekstrin yang diinkubasi $23^{\circ} \mathrm{C}$ akan mengikat molekul lipoprotein yang ada dalam serum lipemik secara maksimal sehingga lipoprotein akan terendapkan dan serum menjadi jernih. Supernatan jernih yang dihasilkan diperiksa kadar glukosanya sehingga didapatkan hasil yang akurat.

Kelemahan dari penelitian ini adalah tingkat kekeruhan dari serum yang digunakan berbeda-beda, serta tidak diketahuinya latar belakang penyakit pasien. Serum lipemik yang digunakan dalam penelitian ini didapatkan dari laboratorium klinik RSUP Dr. Sardjito Yogyakarta kemudian dilakukan penyimpanan pada freezer. Sampel yang didapatkan dalam waktu yang berbeda-beda, maka lama penyimpanan setiap sampel juga berbeda satu sama lain. Konsentrasigammasiklodekstrin yang digunakan dalam penelitian ini juga belum diketahui keefektifitasannya apakah sudah maksimal atau belum, sehingga perlu diadakan penelitian lebih lanjut dengan membandingkan berbagai macam variasi konsentrasi. Inkubasi suhu $23^{\circ} \mathrm{C}$ tidak menggunakan waterbath, karena suhu $23^{\circ} \mathrm{C}$ termasuk suhu dingin, sehingga inkubasi suhu $23^{\circ} \mathrm{C}$ menggunakan kulkas dengan suhu $23^{\circ} \mathrm{C}$.

Penelitian ini menunjukkan serum lipemik tanpa perlakuan menyebabkan hasil pemeriksaan kadar glukosa tinggi palsu sehingga penggunaan metode flokulasi dengan penambahan gamma-siklodekstrin yang diinkubasi suhu $23^{\circ} \mathrm{C}$ terbukti dapat digunakan untuk mengurangi kekeruhan. Metode ini cukup sederhana, tidak berbahaya, lebih efektif dan efisien, sehingga penggunakan gamma-siklodekstrin yang diinkubasi suhu $23^{\circ} \mathrm{C}$ dapat diaplikasikan dengan mudah oleh laboratorium klinis untuk menangani serum lipemik, sehingga hasil pemeriksaan kadar glukosa lebih akurat.

\section{KESIMPULAN}

Ada perbedaan rerata kadar glukosa pada serum lipemik dengan dan tanpa penambahan flokulan gamma-siklodekstrin pada inkubasi suhu $23^{\circ} \mathrm{C}$. Rerata hasil pemeriksaan kadar glukosa dengan penambahan flokulan Gamma-siklodekstrin yang diinkubasi suhu $23^{\circ} \mathrm{C}$ adalah 169,23 $\mathrm{mg} / \mathrm{dl}$ dan tanpa penambahan adalah 267,20 $\mathrm{mg} / \mathrm{dl}$. Rerata selisih kadar glukosa serum lipemik dengan dan tanpa penambahan gamma-siklodekstrin yang diinkubasi suhu $23^{\circ} \mathrm{C}$ adalah $97,97 \mathrm{mg} / \mathrm{dl}$ dengan persentase selisih $(35,23 \%)$.

\section{SARAN}

Penggunaan gamma-siklodekstrin yang diinkubasi suhu $23^{\circ} \mathrm{C}$ dapat diterapkan bagi pengelola manajemen laboratorium klinis sebagai salah satu cara menangani serum lipemik, khususnya kadar glukosa. Perlunya dilakukan penelitian lebih lanjut tentang penambahan gamma-siklodekstrin yang diinkubasi suhu $23^{\circ} \mathrm{C}$ pada serum lipemik dengan variasi konsentrasi gammasiklodekstrin maupun variasi $\mathrm{pH}$. Perlunya dilakukan penelitian lebih lanjut dengan kriteria serum lipemik yang mempunyai kekeruhan seragam. 
DAFTAR PUSTAKA

Anderson, N.R Slim, Gama, S., \& R. Holland, M. . (2003). Lipemia: An Overrated Interference? Continuing Education Topics and Issues. British Journal of Biomedical Science.

Calmarza P, \& Cordero J. (2011). Lipemia interferences in routine clinical biochemical tests. Biochem Med, 21, 160-6.

Castro AR, Morrill WE, \& Pope V. (2000). Lipid Removal from Human Serum Samples. Clin Diagn Lab Immunol, 7(2), 197 -9 .

Cynthia M, Roberts, \& Steven, W. C. (2013). Cyclodextrin Removal of Lipemic Interference: An Attractive Alternative to UItracentrifugation for Satellite Laboratories. Archives of Pathology \& Laboratory Medicine, 137(8), 1027-1028.

Piyophirapong, S., Wontiraporn, W., \& Sribhen, K. (2010). Factitious Resultin Clinical Chemistry Tests Caused by Common Endogenous Interferents. Siriraj Medical Journal, 62(4).

Putri DK. (2016). Perbedaan Kadar Glukosa pada Serum Lipemik dengan dan Tanpa Penambahan Flokulan GammaSiklodekstrin. Poltekkes Kemenkes Yogyakarta.

Sacher R, \& McPherson. (2004). Tinjauan Klinis Hasil Pemeriksaan Laboratorium. Jakarta: EGC.

Sharma A, Anderson K, \& Baker JW. (1990). Flocculation of serum lipoproteins with cyclodextrins: application to assay of hyperlipidemic serum. Clin Chem, 36, 529-32.

Sujono, S., Maulida, Y., \& Sari, M. (2016). Kadar Protein Total dan Ureum Dengan dan Tanpa Penambahan y-cyclodextrin Pada Serum Lipemik. Jurnal Teknologi Laboratorium, 5(1), 16-19. Retrieved from http://www.teknolabjournal.com/ index.php/Jtl/article/view/71

Usha A, \& B N Malawadi. (2016). Lipemic index a tool to measure lipemia. International Journal of Medical Research and Review, 4(4), 613-617. 